\title{
Georgiana UDREA*
}

\section{Review of Uniunea Europeană - un trend în derivă? $O$ analiză a discursului mediatic și a perspectivei tinerilor (The European Union - a Drifting Trend? An Analysis of Media Discourse and Youth Perspectives) by Oana Ștefăniță, Bucharest, comunicare.ro, 2017, 282 pages}

In recent times, the European Union has been confronted with huge challenges and crises, which, in the absence of prompt and effective measures, call into question the future of the European project itself. The political incongruities, the disintegrating tendencies culminating with Brexit, the divisions between northern and southern states over economic crisis and austerity measures, the refugee waves and their poor integration into society, the rise of populist and extremist currents, etc. have caused anger, confusion and fear among Europeans, influencing the relations between member states and public perceptions. In this unstable context, studying people's opinion on the EU and its subtle mechanisms becomes an important and pragmatic effort, as the public has the means to pursue action based on its feelings of support or opposition towards the community block.

Oana Ștefăniță's book, Uniunea Europeană - un trend în derivă? proposes such an insight into the world of young European citizens, investigating their interest in European issues, the EU's place on the agenda of interpersonal conversations, the way they understand and experience the feeling of European belonging, and their perspectives on the future of the Union. The goal of the book is twofold: on the one hand, it is constructed as an analysis of media involvement in the Europeanization process of the national public sphere, and, on the other hand, the book proposes a re-evaluation of the classical theories of agenda setting and media coverage effects.

The author brings an original and valuable contribution to the dedicated literature, giving us the opportunity to read a well-grounded book both theoretically and empirically. In its first part, the volume has the merit of contributing to a deep exploration of fundamental theories and concepts, such as "agenda-setting", "public sphere", "Europeanization" or "European identity". The stated purpose of this work is not to provide an unanimously accepted analytical view on the aforementioned concepts (which is otherwise difficult or even impossible to identify in the broader literature on these topics), but to get the reader familiarised with a variety of approaches explaining the role of media activity in the Europeanization of the nation-

\footnotetext{
* National University of Political Studies and Public Administration, Romania, georgiana.udrea@comunicare.ro.
} 
al public sphere, in crafting the image of the European Union, but also in forging a European sense of identity or belonging.

Analysing the depth implications of the current economic, social and political context, Ștefăniță's book builds on the idea that a viable, functional European project that enjoys the support of its citizens needs an attachment to a common future or a feeling of affiliation to the European community. In their absence, the EU's efforts to institutionalize collective policy solutions, procedures or commitments will remain without echo. Thus, the influence of the media is crucial in supporting Europeanization processes or in crystallizing European identity by creating a direct link between European politics and citizens. The media are responsible for increasing the visibility of European issues, for promoting European actors, for providing a European contextualization of national interest topics and, above all, for building a common basis for the evaluation and interpretation of European issues by synchronizing themselves with the media outlets in the other member states.

At the empirical level, through a research that uses both quantitative and qualitative methods, the book aims primarily to explore the role of the media in establishing the public agenda on European subjects among young people. The author's choice to focus on young educated citizens who speak foreign languages and travel across borders is all the more significant as the future of the EU depends, in the long run, on the younger generations. Also, as current studies show, this category of people regards transnationality as something natural, shows an increased interest towards the EU and tends to assume a European identity alongside other loyalties that are contextual and situational. Equally, the author's option to investigate the perspectives of the Romanian youth responds to an important gap in the mainstream literature, which has only provided scarce and inconsistent studies concerning the population of Eastern European countries in relation to the European issues.

The research results offer relevant information regarding the Europeanization of the media discourse and of the national public sphere, the activity of the media system and how it is reflected in the interpersonal debates, the factors, mechanisms and circumstances that facilitate a feeling of European identity, and the meanings that the young Romanian citizens attribute to being European. Overall, the findings show that we can speak of a correspondence between media and citizens' agendas, especially in the context of EU events involving changes that may directly affect people's domestic daily life (e.g., EP elections). There is, however, a relative dissatisfaction among the respondents about the limited percentage of European topics and their consequences in the national media outlets, which seem to be moving too slowly towards a Europeanized discourse. They mainly remain tributary to facts and events concerning the national plan which are generally addressed in terms of effects and impact at the country level and not at the European level. In this context, the young citizens stress the duty of the Romanian media to balance the deficit of information and communication regarding EU-related topics so that ordinary people are able to understand better the events on the European geopolitical scene and how these may affect them personally.

The perspective of the young people on the European Union's future is (still) relatively optimistic and generally fuelled by their desire to overcome the existing gaps and to feel equal in rights and opportunities to the other citizens Europe. The idea of Europeanness is, in most cases, equivalent to an ideal of civilization, economic development, and access to a higher standard of living. Nevertheless, a question that raises from this book and asks the readers to reflect on is: "To what extent will the young Romanians remain optimistic and enthusiastic about the future of the Union, which they usually depict in rather positive terms?". From the 
author's conclusions, we understand that, in the current context, marked by constant transformations, Romania can no longer be automatically categorized as a Europhile country, not even by reference to the younger generations. While it is true that the traditional public opinion investigation tools, such as the Eurobarometer surveys, still place Romanians in the category of those who predominantly express pro-EU attitudes, at a deeper level of analysis, these optimistic stances appear to be challenged by the recent events. 